\title{
Redefining the production potential of hill pastures using fertiliser nitrogen
}

\author{
M.G. LAMBERT, A.D. MACKAY, B.P. DEVANTIER,D.B. McDOUGALL, D.J. BARKER ${ }^{2}$ and Z.A. PARK-NG \\ ${ }^{1}$ AgResearch, Grasslands Research Centre, PB 11008, Palmerston North \\ ${ }^{2}$ Ohio State University, Columbus, OH 43210, USA \\ greg.lambert@agresearch.co.nz
}

\begin{abstract}
Farmer perceptions of the productive potential of land influence their attitudes to productivity improvement. Pasture production information has generally been gathered within management systems that were considered feasible at the time. A sheep grazing trial was run over 2 years in southern Hawkes Bay hill country in which a Fertiliser treatment involving a very high rate of nitrogen $(\mathrm{N})$ fertiliser $(400 \mathrm{~kg} \mathrm{~N} / \mathrm{ha}$ annually as 8 split dressings of $50 \mathrm{~kg} \mathrm{~N} / \mathrm{ha}$ ) was applied to blocks with historically low, medium or high fertility. Additional fertiliser P and S was also applied as part of the Fertiliser treatment, however the responses were judged to have been mainly due to the $\mathrm{N}$ fertiliser Annual pasture production increased from an average $9.2 \mathrm{t} \mathrm{DM} / \mathrm{ha}$ in Control areas to 17.1 t DM/ha in Fertiliser treatment areas. Similar responses of 18 to $22 \mathrm{~kg} \mathrm{DM} / \mathrm{kg} \mathrm{N}$ fertiliser occurred across the 3 fertility blocks. Average annual pasture production for the historically high fertility-Fertiliser treatment combination was $19.4 \mathrm{t} \mathrm{DM} / \mathrm{ha}$, higher than on most dairy farms. Pasture content of high-fertilityresponsive grasses such as ryegrass increased, at the expense of low-fertility-tolerant grasses such as browntop, legumes such as white clover, and herbaceous weeds. Nitrate leaching measurements suggested annual losses were increased by $25 \mathrm{~kg} \mathrm{~N} /$ ha or $6 \%$ of the $\mathrm{N}$ applied. Given present-day cost structures and returns, these results suggest use of higher rates of $\mathrm{N}$ fertiliser than is current practice is an economic option for hill farmers. However longterm sustainability of systems receiving such high dressings of fertiliser $\mathrm{N}$ requires further investig ation before such an approach should be adopted as part of commercial practice.
\end{abstract}

Keywords: botanical composition, hill country, New Zealand, nitrate leaching, nitrogen fertiliser, pasture production potential

\section{Introduction}

Farmers have aimed to increase productivity from New Zealand hill country since it was cleared of forest and pastures were established about 100 years ago. Achievement of this aim has been aided by improvements in understanding of the function and responsiveness of the components of the farm system (e.g. pasture responses to phosphatic fertiliser), by technological developments (e.g. electric fencing), by external influences (e.g. economic policy), and by farmer perceptions of the productive potential of the resources being utilised (e.g. livestock performance or pasture production potential). For example, improvements in sheep genetics, feeding practices and health programmes have made twinning of hill country ewes accepted commercial practice, whereas 20 years ago many farmers regarded a healthy single lamb as being acceptable. Perceptions of pasture production potential can similarly influence expectations.

Sources that influence farmer perceptions of pasture production potential include research results and industry experience. Research data include measurements of pasture production e.g. cutting trial data for sites throughout New Zealand (e.g. Radcliffe 1974), grazing trial results (e.g. Suckling 1975; Lambert et al. 1983) or estimates based on stocking rate assessments, such as in the land use capability bulletins published by the Ministry of Works \& Development (e.g. Noble 1985). This information gives false impressions of production potential because measurements/estimates were generally obtained under conditions that were considered "feasible" at the time the data were collected e.g. N inputs were predominantly from symbiotic $\mathrm{N}$ fixation by legumes fed with $\mathrm{P}$ and $\mathrm{S}$ fertilisers, and moisture supply was directly from rainfall only. In our experience soil moisture and plant-available mineral nitrogen (Lambert et al . 1982) are manageable factors that limit hill pasture production, however, information on production levels when these limitations are alleviated is scarce.

In 1996 a high fertiliser application treatment was superimposed on a long-term grazing trial in southern Hawke's Bay hill country investigating pasture and animal responses to fertiliser regimes. Responses to this treatment give an indication of the production potential of hill pastures under very high rates of fertiliser $\mathrm{N}$ application and results are presented here.

\section{Experimental}

Site

The trial was conducted from June 1996 to May 1998 
at the AgResearch Ballantrae hill country research station near Woodville in southern Hawke's Bay. The experimental area is at $250-350 \mathrm{~m}$ altitude, and average annual rainfall is about $1200 \mathrm{~mm}$. Soils are Yellow-brown Earths and related steepland soils formed from tertiary sediments and sedimentary drift material, now classified as Brown soils (Hewitt 1998).

\section{Trial paddocks}

Twelve paddocks, $0.55-1.13$ ha in area and having an average slope of $21^{\circ}$ (range $13-26^{\circ}$ ) were selected within the trial area described by Lambert et al. (1996). Four of the paddocks were within a block ("Low") that had received $125 \mathrm{~kg} / \mathrm{ha}$ superphosphate annually during 1974-80 and had not been fertilised subsequently. Another four were in a block ("Med") that had received $125 \mathrm{~kg} / \mathrm{ha}$ superphosphate annually since 1974; and four paddocks were in a block ("High") that received an average $625 \mathrm{~kg} / \mathrm{ha}$ annually during 1975-79 then $375 \mathrm{~kg} / \mathrm{ha}$ superphosphate annually subsequently. All 3 fertility blocks had been set-stocked since 1975 with sheep to achieve similar grazing pressures i.e. paddocks were stocked at a rate proportional to annual pasture production. In 1996 average soil Olsen P status was 6,8 and $23 \mu \mathrm{g} / \mathrm{ml}$ soil for Low, Med and High fertility blocks respectively.

\section{Treatments}

The historical fertiliser regimes for each of the "fertility blocks" (i.e. 0, 125 and $375 \mathrm{~kg} / \mathrm{ha}$ superphosphate annually in spring, for Low, Med and High fertility blocks respectively) were continued. Two paddocks within each fertility block represented a "Control" treatment, and the other two received a "Fertiliser treatment" comprising additional annual inputs of $70 \mathrm{~kg} \mathrm{P}, 50 \mathrm{~kg} \mathrm{~S}$ and 400 $\mathrm{kg} \mathrm{N} / \mathrm{ha}$. Replicate pairs of Control and Fertiliser treatment paddocks were matched for slope and aspect as closely as possible. The $\mathrm{P}$ and $\mathrm{S}$ were applied by hand at the start (in June) of each of the 2 measurement years, as a single dressing of triple superphosphate plus maxi-sulphur superphosphate. The $\mathrm{N}$ fertiliser was applied by hand as urea in 8 dressings throughout each year at the rate of $50 \mathrm{~kg}$ $\mathrm{N} / \mathrm{ha}$, and at a frequency related to the historical seasonal pasture production pattern. Nominal N application dates were 1 June, 24 August, 16 October, 17 November, 12 December, 5 January, 1 February and 14 March for 1996-97 and 1997-98.

\section{Grazing regime}

The paddocks continued to be set-stocked with breeding ewes at a rate proportional to pasture production. Numbers were adjusted when pasture covers and/or ewe liveweights deviated markedly from normal seasonal expectations.

\section{Measurements}

Pasture production was measured using a trim-spellharvest technique and grazing exclusion cages (Lambert et al. 1983), with 14 harvests being made during the two-year period. Individual harvest data were used to calculate seasonal pasture production, based on 4 three-month seasons per year; winter being June - August. Botanical composition was estimated by hand-dissection, drying and weighing sub-samples of herbage harvested from the exclusion cages. Results were combined to give four species categories: high-fertility responsive grasses (e.g. Lolium perenne, Holcus lanatus, Dactylis glomerata, Poa trivialis); low-fertility-tolerant grasses (e.g. Agrostis capillaris, Anthoxanthum odoratum, Cynosurus critatus, Festuca rubra); legumes (e.g. Trifolium repens, T. pratense, Lotus pedunculatus, T. dubium); and weeds (e.g. Hypochaeris radicata, Leontodon taraxacoides, Plantago lanceolata). Three cages were used in each paddock, located on microsites with slopes approximating each paddock's average slope.

\section{Data analysis}

Seasonal and annual pasture production and seasonal botanical composition data were analysed using Genstat, as a split-plot design to test the effect of treatment, year and treatment $\mathrm{x}$ year. Effects involving season were tested using repeated measures ANOVAs. The effect of fertility block was not tested as these blocks were not replicated.

\section{Results}

The Fertiliser treatment markedly increased seasonal and annual pasture production (Table 1). Averaged across the 3 fertility blocks and 2 years, pasture production increased from an average $9.2 \mathrm{t} \mathrm{DM} / \mathrm{ha}$ in the Control paddocks to an average $17.1 \mathrm{t} \mathrm{DM} / \mathrm{ha}$ in the Fertiliser treatment paddocks. Season affected $(\mathrm{P}=0.005)$ the level of response, and there was a tendency for the greatest responses to occur in summer and spring. The size of the seasonal and annual pasture production responses was similar across the fertility blocks (Table 2), the average annual production response ranging from 7.3 to $8.9 \mathrm{t}$ $\mathrm{DM} /$ ha. $\mathrm{N}$ response efficiency (average annual pasture production response calculated as a function of annual fertiliser $\mathrm{N}$ application rate) was similar across fertility blocks and ranged from 18.2 to 22.3 $\mathrm{kg} \mathrm{DM} / \mathrm{kg} \mathrm{N}$ applied (Table 2). 
Table 1 Pasture production (kg DM/ha) averaged across the fertility blocks, for the Control and Fertiliser treatments, the size of the differences between the treatments $(\mathrm{kg} \mathrm{DM} / \mathrm{ha})$ and the statistical significance of those differences.

\begin{tabular}{|c|c|c|c|c|c|c|c|c|c|c|}
\hline & \multicolumn{5}{|c|}{ - Year 1} & \multicolumn{5}{|c|}{ - Year 2} \\
\hline & Win & Spr & Sum & Aut & Ann & Win & Spr & Sum & Aut & Ann \\
\hline Control & 1059 & 2826 & 3071 & 2439 & 9394 & 916 & 2768 & 3543 & 1865 & 9092 \\
\hline Fertiliser & 1860 & 5254 & 5899 & 4512 & 17525 & 1927 & 5249 & 6960 & 2574 & 16710 \\
\hline Difference & 802 & 2428 & 2828 & 2073 & 8131 & 1011 & 2482 & 3416 & 709 & 7618 \\
\hline Significance & 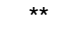 & 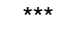 & 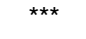 & 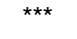 & 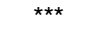 & $\star \star \star *$ & $\star \star$ & 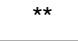 & * & 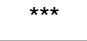 \\
\hline
\end{tabular}

Win $=$ winter, $\mathrm{Spr}=$ spring, Sum $=$ summer, Aut $=$ autumn, Ann $=$ annual total.

Win $=$ winter, Spr = spring, Sum $=$ st ${ }^{\star *}<0.05,{ }^{\star \star} P<0.01,{ }^{\star \star \star} P<0.001$

Table 2 Average seasonal and annual pasture production (kg DM/ha) for Control and Fertiliser treatments within each of three fertility blocks (Low, Med, High), pasture production differences between treatments, and annual $\mathrm{N}$ response efficiencies (kg DM/kg N applied).

\begin{tabular}{llccccc}
\hline & & Winter & Spring & Summer & Autumn & Annual \\
\hline \multirow{2}{*}{ Low } & Control & 669 & 1984 & 2296 & 1684 & 6633 \\
& Fertiliser & 1394 & 4823 & 6094 & 3231 & 15542 \\
& Difference & 725 & 2838 & 3798 & 1547 & 8909 \\
& N response efficiency & & & 22.3 \\
\hline \multirow{2}{*}{ Med } & Control & 1020 & 2764 & 2974 & 2208 & 8966 \\
& Fertiliser & 1835 & 5002 & 6063 & 3485 & 16385 \\
& Difference & 815 & 2238 & 3089 & 1277 & 7419 \\
& N response efficiency & & & & 2563 & 18.5 \\
\hline High & Control & 1273 & 3642 & 4651 & 3912 & 12129 \\
& Fertiliser & 2452 & 5930 & 7131 & 1349 & 7296 \\
& Difference & 1179 & 2288 & 2480 & & 18.2 \\
\hline
\end{tabular}

Figure 1 Average seasonal contribution (\%) of high-fertility-responsive grasses, low-fertility-tolerant grasses, legumes and weeds to pasture production in Control and Fertiliser (Fert) treatments over the 2 years of the trial. Bars represent annual LSD (5\%) values apart from those for weeds which are presented for individual seasons.

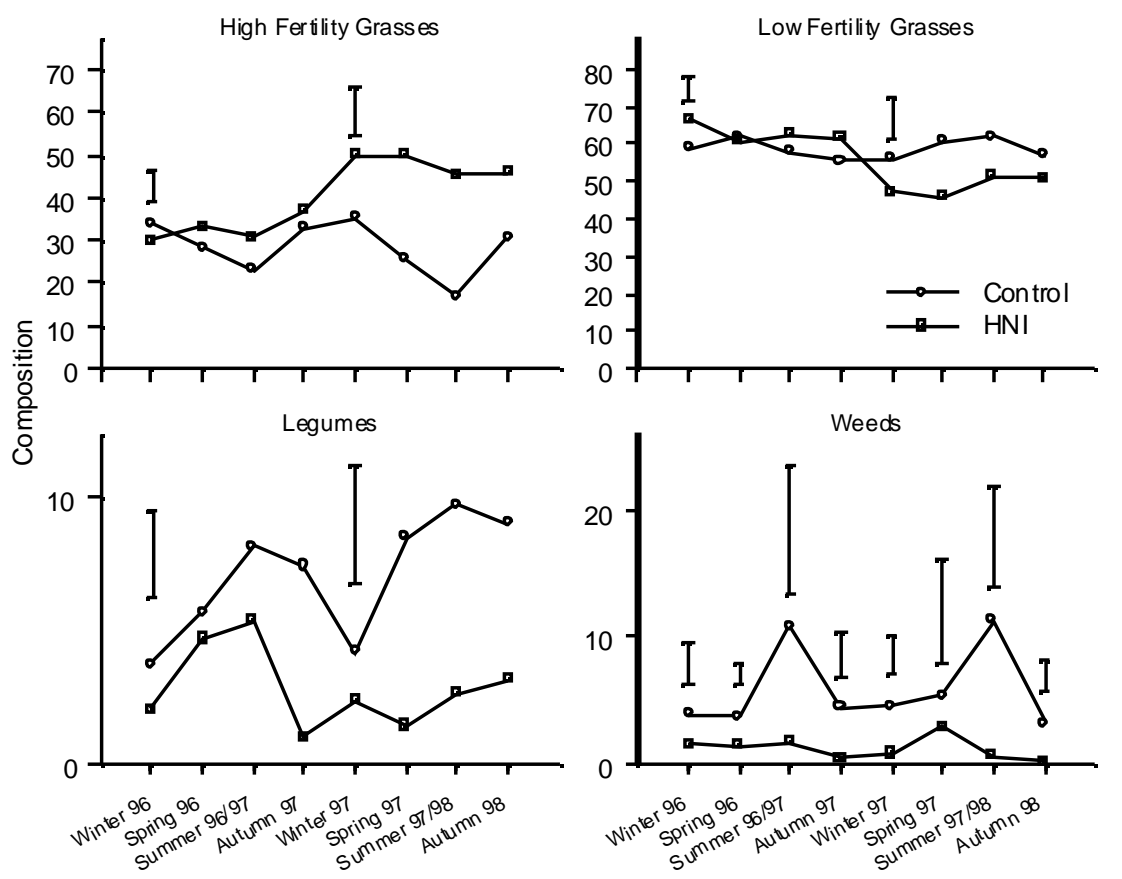


The Fertiliser treatment did not significantly increase the high-fertility-responsive grass percentage in the first year $(\mathrm{P}=0.325)$, but $\operatorname{did}(\mathrm{P}=0.005)$ in year 2 (Figure 1), i.e. there was a treatment $\mathrm{x}$ year interaction $(\mathrm{P}=0.007)$. There was also a significant $(\mathrm{P}=0.048)$ treatment $\mathrm{x}$ year interaction for low-fertility-tolerant grass percentage, because there was little effect $(\mathrm{P}=0.149)$ in the first year, but a strong trend $(\mathrm{P}=0.071)$ towards a decline in content in Fertiliser treatment pastures in year 2 . There was also a tendency $(\mathrm{P}=0.067)$ for the Fertiliser treatment to depress legume content in year 1 , and this effect was statistically significant $(\mathrm{P}=0.026)$ in year 2 . On average, weed percentage was decreased by the Fertiliser treatment $(\mathrm{P}=0.028)$, however this effect depended on season (treatment $\mathrm{x}$ season interaction $\mathrm{P}=0.015)$. The depression in weed percentage was much greater $(\mathrm{P}=0.026)$ in summer than in the other seasons (Figure 1).

\section{Discussion}

The effect of the Fertiliser treatment on pasture production was immediate (the size of the response in the first winter and spring was similar to that in the second year) and large. There was an average $85 \%$ increase in annual pasture production. The annual production level achieved on the historical "High" fertility block (19.4 t DM/ha) was higher than that achieved on most high producing dairy farms (de Klein et al. 2000).

The response in annual pasture production was similar across fertility blocks ( 7.4 to 8.9 t DM/ha). This similarity, coupled with the probability that $\mathrm{P}$ and $\mathrm{S}$ were not major limitations to plant growth on the High fertility block because of years of above maintenance $\mathrm{P}$ and $\mathrm{S}$ application, suggests the response on all fertility blocks was primarily driven by enhanced supply of plant available $\mathrm{N}$ rather than by the additional annual dressings of $\mathrm{P}$ and $\mathrm{S}$. This is supported by Ball et al. (1982) who concluded after reviewing available evidence that "even when little additional $\mathrm{P}$ fertiliser was applied the $\mathrm{N}$ response was essentially independent of additional fertiliser P”. This was because grasses had a much lower $\mathrm{P}$ requirement than clovers. This suggests that where $\mathrm{N}$ inputs to pastoral systems are to be dominantly from fertiliser rather than symbiotically fixed $\mathrm{N}$, markedly lower inputs of $\mathrm{P}$ and $\mathrm{S}$ will be required, which saving can be offset against the cost of the fertiliser $\mathrm{N}$.

If the response is solely attributed to the $\mathrm{N}$ component of the fertiliser, then the $\mathrm{N}$ response efficiencies of 18 to 22 are very high given the large annual $\mathrm{N}$ input. While $\mathrm{N}$ response efficiencies in hill pastures of the order of $20 \mathrm{~kg} \mathrm{DM} / \mathrm{kg} \mathrm{N}$ applied have been recorded for lower rates of $\mathrm{N}$ application, particularly when measured in grazing rather than mowing trials where clippings are removed and potential for fertiliser $\mathrm{N}$ to be recycled is reduced (e.g. Ball et al. 1982), decreasing marginal returns should mean response efficiencies would be much less than 20 at an annual application rate of $400 \mathrm{~kg} \mathrm{~N} / \mathrm{ha}$. The recycling of $\mathrm{N}$ that occurs in grazed hill pastures means that responses to fertiliser $\mathrm{N}$ application can occur over several seasons following application (Lambert \& Clark 1986). Long-term response efficiencies to $\mathrm{N}$ application have almost certainly been under-estimated where trials are run under mowing rather than grazing regimes, and where measurements are discontinued before the response has fully expressed itself.

One of the potential environmental impacts of increased use of fertiliser $\mathrm{N}$ is greater leaching of nitrate from the soil profile. We measured nitrate leaching as part of the overall study and although the data are not reported here, preliminary results (MG Lambert et al. unpublished data) suggest that annual nitrate loss from the Control paddocks was about 6 $\mathrm{kg} \mathrm{N} / \mathrm{ha}$ and from the Fertiliser treatment paddocks $31 \mathrm{~kg} \mathrm{~N} / \mathrm{ha}$ i.e. an increased nitrate loss of $25 \mathrm{~kg} \mathrm{~N} /$ ha, or $6 \%$ of the fertiliser $\mathrm{N}$ applied. This leaching loss is a little less than that of an average dairy farm using $50 \mathrm{~kg} \mathrm{~N} / \mathrm{ha}$ and producing $13.0 \mathrm{t} \mathrm{DM} / \mathrm{ha}$ annually (36 kg N/ha), but much less than a dairy farm using $200 \mathrm{~kg} \mathrm{~N} / \mathrm{ha}$ and producing $18.5 \mathrm{~kg} \mathrm{DM} /$ ha for which annual losses are about $77 \mathrm{~kg} \mathrm{~N} / \mathrm{ha}$ (de Klein et al. 2000). This comparison is confounded because leaching losses from cattle exceed those from sheep (Williams \& Haynes 1994); however the comparison still suggests that hill systems may be less leaky than systems on easier topography, at least in the short term. The NZ Fertiliser Manufacturers' Research Association Code of Practice for Fertiliser Use (www.fertresearch.org.nz) suggests that annual applications of more than $200 \mathrm{~kg} \mathrm{~N} / \mathrm{ha}$ may lead to unacceptably high levels of nitrate leaching. However the Code acknowledges that higher rates may be possible without adverse effects where there are mitigating factors, such as with soils of higher $\mathrm{C}: \mathrm{N}$ ratio, as is the case with hill soils.

The general effect of the Fertiliser treatment relative to the Control in terms of botanical composition was for an increased high-fertility-responsive grass percentage, at the expense of low-fertility-tolerant grasses, legumes and weeds. Most of these changes would be regarded as positive by farmers, with the exception of the decline in legume content. However, one of the major reasons for use of legumes in pastures is their symbiotic $\mathrm{N}$-fixing ability, and the importance 
of this is much less where high rates of $\mathrm{N}$ fertilisation are the ongoing practice. The Fertiliser treatment effect on pasture botanical composition was greater in year 2 than in year 1. This slow rate of change, coupled with the relatively small magnitude of the changes in response to a dramatic change in supply of $\mathrm{N}$ (the most limiting plant nutrient), suggests that the botanical composition of such pastures is wellbuffered and that increases in high-fertility responsive grasses might be expected to continue over a number of years.

Estimates of potential stock carrying capacity were made more than 20 years ago using advice from local consultants during development of the New Zealand Land Use Capability Classification. That work estimated "potential carrying capacity" for land similar to that of the trial area, at $19 \mathrm{SU}$ (stock units)/ha as compared to that being achieved by "top farmers" at that time of $16 \mathrm{SU} /$ ha (Noble 1985). Assuming an annual intake of $595 \mathrm{~kg} \mathrm{DM} / \mathrm{SU}$ (Coop 1965) and an $80 \%$ utilisation of pasture production, that $19 \mathrm{SU} / \mathrm{ha}$ potential carrying capacity would be associated with a pasture production potential of about $14.1 \mathrm{t} \mathrm{DM} /$ ha. Using the same assumptions, the potential carrying capacity for the "High" fertility-Fertiliser treatment paddocks in the current trial would be $26 \mathrm{SU} / \mathrm{ha}$.

This trial was run to stretch the boundaries of current practice, and to assess some of the production and environmental consequences. The production consequences were dramatic and our limited data suggest the environmental consequences were not overly severe in terms of nitrate leaching. Simple economic analysis shows that with the high $\mathrm{N}$ response efficiencies measured the extra feed grown by $\mathrm{N}$ fertilisation was at very low marginal cost (about $7 \mathrm{c} / \mathrm{kg}$ DM). However, cost-benefit analysis should take into account fixed as well as variable costs. Such large increases in pasture DM production mean the fixed costs associated with owning or leasing land would be much lower per unit DM produced, and provided this DM was efficiently utilised the costbenefit outcome would be very favourable indeed.

It is our view that potential exists for greatly increasing hill country production levels using fertiliser N. However we caution that potential onand off-site impacts, including effects on nitrate and greenhouse gas emissions, soil and pasture condition and nutrient cycling require further study in order to establish whether such high $\mathrm{N}$ application rates would affect long-term sustainability. Also, a large proportion of the extra pasture grown occurred in spring and summer when feed supply is commonly not limiting on summer-moist hill country farms and where mechanical harvesting of surpluses is difficult, so new farming systems would need to be devised to profitably utilise that extra feed.

\section{ACKNOWLEDGEMENTS}

Thanks to John Napier and Ballantrae field staff for assistance with conduct of the field trial; and to David Baird and Roger Littlejohn for statistical advice.

\section{REFERENCES}

Ball, P.R.; Luscombe, P.C.; Grant, D.A. 1982. Nitrogen on hill country. pp. 133-148. In: Nitrogen fertilisers in New Zealand agriculture. Ed. P.B. Lynch. New Zealand Institute of Agricultural Science.

Coop, I.E. 1965. A review of the ewe equivalent system. Agricultural Science 11: 13-18.

de Klein, C.; Patton, P.; Ledgard, S. 2000. An evaluation of a strategic de-stocking regime for dairying to improve nitrogen efficiency and reduce nitrate leaching from dairy farms in nitrate-sensitive areas. Proceedings of the New Zealand Grassland Association 62: 105-110.

Hewitt, A. E. 1998: New Zealand Soil Classification ( $2^{\text {nd }}$ ed). Landcare Research Science Series 1.

Lambert, M. G.; Barker, D. J.; Mackay, A. D.; Springett, J. 1996: Biophysical indicators of sustainability of North Island hill pasture systems. Proceedings of the New Zealand Grassland Association 57: 31-36.

Lambert, M. G.; Clark, D. A. 1986. Effects of lateautumn nitrogen application on hill country pastures and sheep production. Proceedings of the New Zealand Grassland Association 47: 211-215.

Lambert, M. G.; Clark, D. A.; Grant, D. A.; Costall, D. A.; Fletcher, R. W. 1983: Influence of fertiliser and grazing management on North Island hill country. 1. Herbage accumulation. New Zealand Journal of Agricultural Research 26: 95-108.

Lambert, M.G.; Luscombe, P.C.; Clark, D.A. 1982. Soil fertility and hill country production. Proceedings of the New Zealand Grassland Association 43: 153-160.

Noble, K.E. 1985. Land use capability classification of the southern Hawke's Bay - Wairarapa region. Bulletin to accompany New Zealand land resource inventory worksheets. Water \& Soil Miscellaneous Publication 74. ISSN 0110-4705. 128 pp.

Radcliffe, J.E. 1974. Seasonal distribution of pasture production in New Zealand 1. Methods of measurement. New Zealand Journal of Experimental Agriculture 2: 337-40.

Suckling, F. E. T. 1975: Pasture management trials on unploughable hill country at Te Awa. 3. Results for 1959-69. New Zealand Journal of Experimental 
Agriculture 3: 351-436.

Williams, P.H.; Haynes, R.J. 1994. Comparison of initial wetting pattern, nutrient concentrations in soil solution and the fate of ${ }^{15} \mathrm{~N}$-labelled urine in sheep and cattle urine patch areas of pasture soil. Plant and Soil 162: 49-59. 